\title{
PENELITIAN
}

\section{PENGARUH ASAP ROKOK KRETEK TERHADAP IMUNITAS SELULER TIKUS BETINA STRAIN LMR*}

\author{
Rosila Idris, Hadi Hartamto**
}

\begin{abstract}
Abstrak
Penelitian eksperimental ini bertujuan mengetahui pengaruh asap rokok terhadap sistem imun seluler. Ada tiga kelompok tikus yang dipajan selama 7, 14, dan 21 siklus estrus dibandingkan dengan kontrol yang tidak terpajan asap rokok. Parameter yang dinilai adalah persentase blastranformasi limfosit T yang dikultur selama 72 jam. Hasilnya pada pemajanan selama 7 dan 14 siklus estrus tidak menunjukkan perbedaan yang bermakna dibandingkan kontrol, sedangkan pemajanan pada 21 siklus terdapat perbedaan yang bermakna. Hal ini dapat diartikan baru pada pemajanan 21 siklus terjadi gangguan imunitas seluler. Pada pemajanan 7 siklus dibandingkan 21 siklus terdapat perbedaan blastransformasi limfosit T secara signifikan ( $\mathrm{p}=0.004)$, sedangkan pada pemajanan 14 dibandingkan 21 siklus terlihat perbedaan blastransformasi limfosit T tidak bermakna ( $\mathrm{p}=0.986)$. Dari hasil tersebut dapat disimpulkan imunitas seluler tikus akan terganggu setelah pemajanan asap rokok 21 siklus estrus. Berdasarkan hasil penelitian ini kemungkinan imunitas seseorang yang terpajan asap rokok cukup lama dapat terganggu. Perlu penelitian lebih lanjut dengan pemajanan lebih dari 21 siklus untuk mengetahui timbulnya penyakit kanker dan kardiovaskuler.
\end{abstract}

Kata kunci: blastransfomasi, limfosit T, perokok pasif.

\begin{abstract}
Experimental research was done to understand the effect of cigarette smoke to cellular immunity. In this research, 3 groups of rats were exposed by cigarette smoke for 7, 14, and 21 estrous cycles. Each group had a control group that was not exposed by cigarette smoke. Percentage of $T$ lymphocytes blastransformation that cultured in 72 hours was used as the parameter. T Lymphocytes blastransformation was measured with the blood culture preparation. The result showed the groups exposed in 7 and 14 cycles had no significant influence in cellular immunity. But the groups exposed in 21 cycles showed a decline of the cellular immunity function. This research has provided that the cellular immunity of the rats declines by the cigarette smoke in 21 cycle's exposure. Based on this research, people who are exposed by cigarette smoke for long time can decrease of their immunity, especially cellular immunity.
\end{abstract}

Key words: blastransformation, passive smoker, T lymphocyt.

\section{LATAR BELAKANG}

Asap rokok telah diketahui mengandung kurang lebih 4.800 jenis bahan kimia, dan 60 di antaranya bersifat karsinogenik pada hewan dan manusia (IARC, 2004). Bahan yang bersifat karsinogen ini menurut Yusuf dan Saad (1991) lebih banyak terdapat dalam asap rokok samping (side stream smoke) yang diisap perokok pasif, misalnya CO 5 kali lipat, benzopirin 3 kali lipat, dan ammonia 50 kali lipat dibandingkan dengan asap yang dinikmati perokok aktif.
Bahan-bahan tersebut dapat bertahan selama beberapa jam di ruangan sesudah kegiatan merokok dihentikan. Studi epidemiologik membuktikan dugaan pajanan asap rokok meningkatkan insidens kanker pada prenatal dan anak yang dilahirkan (Sheung, 2006).

Tikus percobaan yang dipajan dengan asap rokok dalam waktu lama terjadi penurunan respon antibodi yang bermakna dan reaktivitas limfosit $\mathrm{T}$ menurun (Holt, 1977). Pengaruh pemajanan asap rokok terhadap tikus dan mencit dapat menurunkan respon dan jumlah proliferasi limfosit T (Kalra, 2000). Hal ini perlu dibuktikan dengan penelitian eksperimental. 
Dalam penelitian ini yang diteliti adalah imunitas seluler. Hewan cobanya adalah tikus betina (strain LMR). Dipilihnya tikus betina berdasarkan kenyataan di masyarakat, kebanyakan yang menjadi perokok pasif adalah perempuan. Untuk mengetahui imunitas selulernya dilakukan uji blastransformasi limfosit $\mathrm{T}$.

Hasil penelitian diharapkan dapat memberi andil dalam memperkuat pendapat tentang bahaya asap rokok bagi kesehatan, dan sebagai bahan bagi petugas kesehatan untuk memberikan nasehat dan menjaga lingkungan rumah sakit bebas asap rokok. Hasil penelitian juga dapat mendorong keluarnya undang-undang atau peraturan daerah yang melindungi perokok pasif. Misalnya peraturan atau undang-undang yang membatasi merokok di tempat umum. Di beberapa negara telah ada peraturan yang membatasi merokok di tempat umum. Di Indonesia perokok pasif telah mendapat perlindungan dari pemerintah yang terdapat pada PP no.19/2003 tentang pengamanan rokok bagi kesehatan khususnya pada pasal Kawasan Tanpa Rokok. Di DKI khususnya telah dikeluarkan PERDA no.2/2005 tentang penanggulangan pencemaran udara terutama larangan merokok di tempat umum.

\section{METODOLOGI}

Eksperimen ini menggunakan rancangan acak kelompok dengan 4 jenis perlakuan yang merupakan lama pemajanan asap rokok masingmasing 7, 14, dan 21 siklus estrus, serta kelompok tanpa pemajanan asap rokok. Penggunaan lama pemajanan dengan kelipatan 7 siklus estrus berdasarkan konversi lamanya siklus menstruasi pada perempuan (30 hari) ke siklus estrus tikus (4-5 hari). Jangka waktu ini diperkirakan sudah memberikan gambaran yang nyata apabila memang terjadi perubahan akibat pemajanan asap rokok. Ulangan (replikasi) tiap kelompok perlakuan berdasarkan rumus Federer: $(\mathrm{t}-1)(\mathrm{n}-1)>15, \mathrm{t}=$ jumlah perlakuan, dan $\mathrm{n}=$ jumlah ulangan (Gunawan, 1981). Dari perhitungan dengan rumus tersebut jumlah ulangan yang didapatkan adalah 6 untuk setiap perlakuan.
Tikus yang dipakai dalam penelitian ini adalah tikus betina strain LMR yang berumur 3-4 bulan, dengan berat badan 120-125 gram. Semua tikus dalam keadaan sehat dan mempunyai siklus estrus yang teratur. Karena pada setiap perlakuan terdiri dari 1 seri dan masing-masing mempunyai kontrol, tiap jenis perlakuan mempunyai ulangan 6 , maka jumlah tikus yang digunakan 36 ekor.

Perokok berat menghabiskan 40 batang rokok per hari, dan berat badan wanita dewasa sekitar $45 \mathrm{~kg}$. Tikus dewasa mempunyai berat badan sekitar 120-125 gram, sehingga bila dikonversikan dengan berat badan wanita dan toleransi tikus, maka setiap tikus betina per hari mendapat asap dari 1 batang rokok.

Pemajanan dilakukan setiap hari, dan jumlah batang rokok yang dibakar per hari sesuai dengan jumlah tikus yang ada dalam kandang perlakuan. Dengan demikian jumlah batang rokok yang diperlukan: Hari ke $1 \mathrm{~s} / \mathrm{d}$ hari ke 35 (18 ekor tikus) $=630$ batang, hari ke $36 \mathrm{~s} / \mathrm{d}$ hari ke 70 (12 ekor tikus $)=420$ batang, dan hari ke $71 \mathrm{~s} / \mathrm{d}$ hari ke $105(6$ ekor tikus $)=210$ batang. Total rokok yang diperlukan dalam penelitian ini kurang lebih 1.260 batang, dan rokok yang digunakan adalah rokok kretek. Rokok kretek digunakan karena perokok kretek di Indonesia lebih banyak dar ipada perokok putih.

Perokok pasif yang dianggap dalam penelitian ini adalah perokok yang menghisap asap rokok yang keluar dari rokok yang terbakar. Dari batasan tersebut maka asap rokok yang dipakai untuk pemajanan berasal dari asap rokok yang keluar dari rokok yang terbakar dan berada dalam kandang pada pipa yang dihubungkan dengan alat pengisap. Alat pengisap ini hanya digunakan jika terlihat api rokok akan mati. Setelah rokok terbakar habis, tikus dipindahkan dari kandang percobaan ke kandang yang biasa dipakai untuk pemeliharaan di laboratorium.

Kandang percobaan merupakan kandang pemajanan dengan asap rokok berukuran $50 \mathrm{X} 50 \mathrm{X} 40 \mathrm{~cm}$ yang dibuat dari besi dan anyaman jeruji kawat. 
Atap dan dindingnya dilapisi tripleks, sedangkan kurang lebih $5 \mathrm{~cm}$ di bawah alas kandang dibuat ruang tertutup dengan beberapa lubang untuk pipa tempat menaruh rokok. Pipa-pipa ini dihubungkan dengan alat pengisap. Pada dinding kandang dibuat juga beberapa lubang ventilasi dan celah segi empat yang ditutup kaca untuk mengamati keadaan dalam kandang selama berlangsung pemajanan.

Tikus betina strain LMR berjumlah 36 ekor yang berumur antara 3-4 bulan dengan berat badan antara 120-125 gram dibagi menjadi 3 kelompok. Kelompok I terdiri dari 2 grup tikus, yaitu grup kontrol (K1) dan grup perlakuan yaitu tikus betina yag dipajan asap rokok selama 7 siklus estrus (PI). Kelompok II terdiri dari 2 grup tikus, yaitu grup kontrol (K2) dan grup perlakuan dipajan asap rokok selama 14 siklus estrus (P2). Kelompok III terdiri dari 2 grup tikus, yaitu grup kontrol (K3) dan grup perlakuan dipajan asap rokok selama 21 siklus estrus (P3).

Parameter yang diteliti dalam penelitian ini adalah blastransformasi limfosit T. Darah tikus percobaan dan darah tikus kontrol dikultur menggunakan medium kultur RPMI 1640. Proliferasi sel limfosit dirangsang dengan Phytohemaglutinin (PHA) dan Fetal Calf Serum yang ditambahkan pada medium kultur.

Kultur diinkubasi dalam inkubator $\mathrm{CO}_{2}$ selama 72 jam, kemudian kultur dipanen, dilihat dari sediaan hapus darah tikus percobaan maupun kontrol yang dimatikan setelah 35 hari, 70 hari, dan 105 hari dipajan dengan asap rokok kretek. Metode kultur untuk memperoleh blastranformasi limfosit dari darah tikus merupakan modifikasi metode Matangkasombut 1972 dan Coligan 2005, dan nilai normal blastranformasi limfosit $69 \%$ dari total 100 limfosit yang dihitung.

\section{BAHAN DAN CARA KERJA}

Kultur sel darah tikus (diambil dari jantungnya) dilakukan dalam Tissue Culture (TC) flask steril dengan cara $0.8 \mathrm{ml}$ darah yang diambil dari jantung tikus + medium kultur yaitu: 5 ml RPMI $1640+$ $0,8 \mathrm{ml}$ Fetal calf serum $+0,8 \mathrm{ml}$ Pythohemagglutinin (PHA), suatu mitogen yang merangsang mitosis. Kultur tersebut diinkubasi dalam inkubator $\mathrm{CO}_{2}(5 \%)$ selama 72 jam pada $37^{\circ} \mathrm{C}$. Setelah 72 jam inkubasi, kultur dipindahkan ke dalam tabung sentrifus, kemudian disentrifus dengan kecepatan 1000 RPM selama 10 menit. Supernatan dibuang. Kultur lalu ditambahkan larutan Hank $5 \mathrm{ml}$ dan disentrifus dua kali dengan kecepatan 1000 RPM selama 10 menit.

Selanjutnya kultur ditambahkan larutan hipotonik KCL 0,56\% untuk melisiskan sel dan selanjutnya diinkubasi selama 20 menit dengan suhu $37^{\circ} \mathrm{C}$. Proses selanjutnya, kultur ditambahkan larutan Carnoy 10 tetes kemudian disentrifus 10 menit sampai larutan menjadi jernih. Setelah jernih, larutan dibuat preparat dengan pewarnaan Giemsa $2 \%$ dan dilihat pada pembesaran 40 kali dan 100 kali.

\section{HASIL}

Hasil blastransformasi limfosit $\mathrm{T}$ dari tikus kelompok I,II, dan III dapat dilihat dalam Tabel 1. Sedangkan Tabel.2. memperlihatkan bahwa rata-rata persentase jumlah proporsi blastransformasi limfosit T kelompok K1 adalah $51.63+7.43$ dan kelompok P1 adalah $56.75+$ 10.44. Rata-rata persentase jumlah proporsi blastransformasi limfosit T kelompok K2 61.83 $+6,39$ dan kelompok P2 adalah 63,29 + 5.75. Rata-rata persentase jumlah proporsi blastransformasi limfosit T kelompok K3 62.99 + 1,33 dan kelompok P3 adalah 62.03 + 5.06. 
Tabel 1.

Daftar Jumlah Blastransformasi Limfosit T dari 36 Tikus Betina. Dalam Kelompok I: 7 siklus estrus (35 hari), II: 14 siklus estrus (70 hari) dan III: 21 siklus estrus (105 hari)

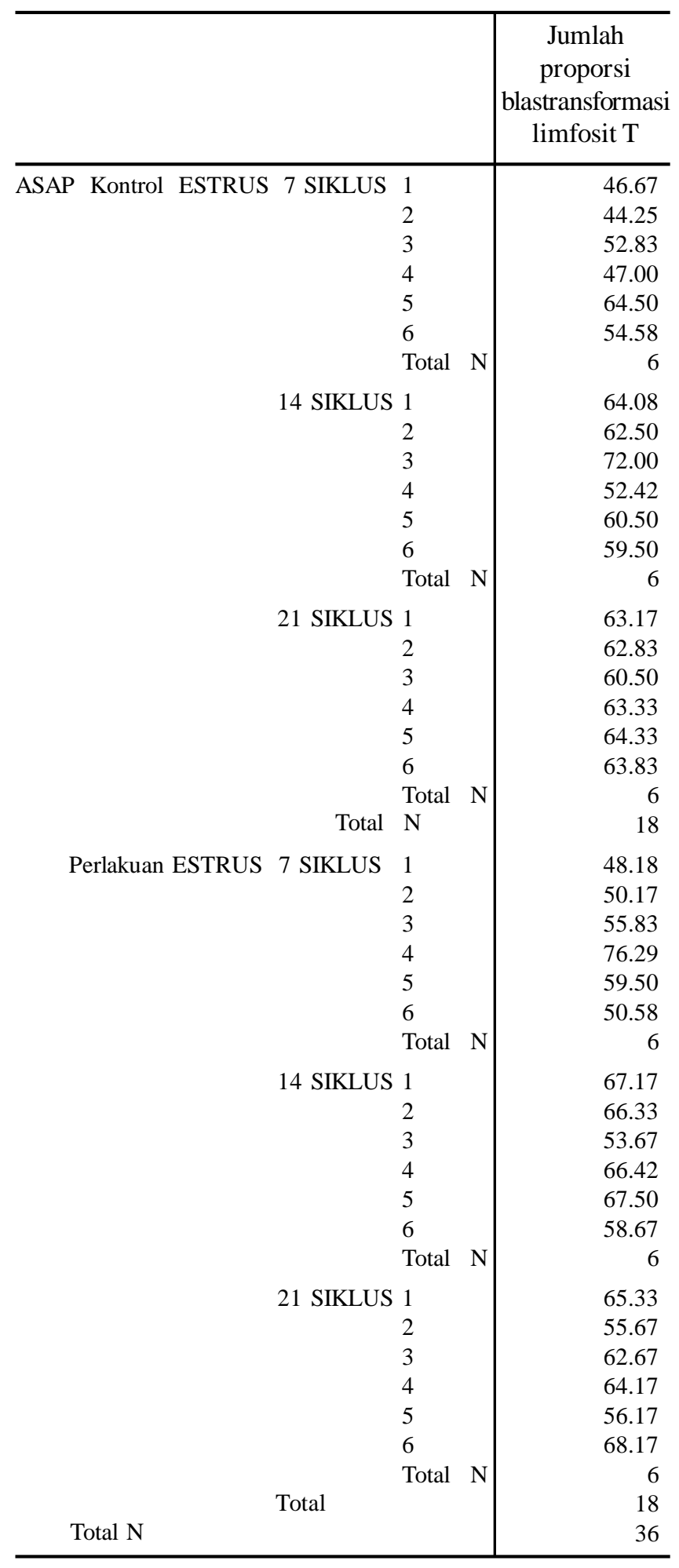

Tabel 2.

Daftar Rata-rata dan Standar Deviasi Jumlah Blastransformasi Limfosit T dari 36 Tikus Betina dalam Kelompok I: 7 siklus estrus (35 hari), II: 14 siklus esturs (70 hari), dan III: 21 siklus estrus (105 hari)

\begin{tabular}{|c|c|c|c|c|}
\hline ASAP & ESTRUS & Mean & Std. Deviasi & $\mathrm{N}$ \\
\hline Kontrol & $\begin{array}{lrl}\text { (K1) } & 7 & \text { siklus } \\
\text { (K2) } & 14 & \text { siklus } \\
\text { (K3) } & 21 & \text { siklus } \\
\text { Total } & & \end{array}$ & $\begin{array}{l}51.63 \\
61.83 \\
62.99 \\
58.82\end{array}$ & $\begin{array}{l}7.43 \\
6.39 \\
1.33 \\
7.50\end{array}$ & $\begin{array}{r}6 \\
6 \\
6 \\
18\end{array}$ \\
\hline Perlakuan & $\begin{array}{lrl}(\mathrm{P} 1) & 7 & \text { siklus } \\
(\mathrm{P} 2) & 14 & \text { siklus } \\
(\mathrm{P} 3) & 21 & \text { siklus } \\
\text { Total } & & \end{array}$ & $\begin{array}{l}56.75 \\
63.29 \\
62.03 \\
30.69\end{array}$ & $\begin{array}{r}10.44 \\
5.75 \\
5.06 \\
7.60\end{array}$ & $\begin{array}{r}6 \\
6 \\
6 \\
18\end{array}$ \\
\hline Total & $\begin{array}{rr}7 & \text { siklus } \\
14 & \text { siklus } \\
21 & \text { siklus } \\
\text { Total } & \end{array}$ & $\begin{array}{l}54.19 \\
62.56 \\
62.51 \\
59.75\end{array}$ & $\begin{array}{l}9.04 \\
5.85 \\
3.56 \\
7.50\end{array}$ & $\begin{array}{l}12 \\
12 \\
12 \\
36\end{array}$ \\
\hline
\end{tabular}

Uji normalitas dan homogenitas berdasarkan cara Kalmogorov-Smirnov dan Levene diperoleh $p=0.133(p>0.05)$ (Santoso S, 2001). Dengan demikian data yang diperoleh dapat diolah menggunakan uji statistik T-test dan parametrik anova dua arah. T-test (uji statistik antara 2 variabel "independent") digunakan untuk membandingkan persentase jumlah blastransformasi limfosit $\mathrm{T}$ antara kelompok K1 dan P1 hasilnya tidak terdapat perbedaan bermakna $(\mathrm{p}=0.58)$ (Tabel 3). Hal ini berarti bahwa selama pemajanan 7 siklus tidak mempengaruhi imunitas seluler tikus percobaan.

Tabel 3.

Uji T-test Persentase Jumlah Proporsi Blastransformasi Limfosit T dari 12 tikus betina dalam Kelompok Perlakuan I (K1dan P1) 7 siklus estrus (35 hari)

\begin{tabular}{l|c|c|c|c}
\hline & Levene's & Test & & \\
\hline & F hitung & Signifikan $(\mathrm{p})$ & $\mathrm{t}$ & $\mathrm{df}$ \\
\hline \% Blastranformasi & 0.312 & 0.589 & -.979 & 10 \\
Varian K1 dan P1 & & & -979 & 9.033 \\
\hline
\end{tabular}

Uji persentase jumlah blastransformasi limfosit $\mathrm{T}$ antara grup $\mathrm{K} 2$ dan $\mathrm{P} 2$ dengan T-test menunjukkan tidak terdapat perbedaan bermakna $(\mathrm{p}=0.85)$ (Tabel 4). Ini berarti pemajanan selama 14 siklus estrus belum ada pengaruhnya terhadap imunitas seluler tikus percobaan. 
Tabel 4.

T-test Persentase Jumlah Proporsi Blastransformasi Limfosit T dari 12 tikus betina dalam Kelompok Perlakuan II (K2, P2) 14 siklus estus (70 hari)

\begin{tabular}{l|c|c|c|c}
\hline & Levene's & Test & & \\
\hline & F hitung & Signifikan $(\mathrm{p})$ & $\mathrm{t}$ & $\mathrm{df}$ \\
\hline \% Blastranformasi & 0.037 & 0.850 & -.416 & 10 \\
Varian K2 dan P2 & & & -416 & 9.890 \\
\hline
\end{tabular}

Uji persentase jumlah proporsi blastransformasi limfosit $\mathrm{T}$ antara kelompok K3 dan P3 dengan T-test menghasilkan perbedaan bermakna $\mathrm{p} .=0.01$. Hal ini berarti setelah pemajanan 21 siklus estrus terjadi penurunan jumlah blastransformasi limfosit $\mathrm{T}$ (Tabel 5).

Tabel 5.

T-test Persentase Jumlah Proporsi Blastransformasi Limfosit $\mathrm{T}$ dari 12 tikus betina dalam Kelompok Perlakuan III

(K3 dan P3) 21 siklus estrus (105 hari)

\begin{tabular}{l|c|c|c|c}
\hline & Levene's & Test & & \\
\hline & F hitung & Signifikan $(\mathrm{p})$ & $\mathrm{t}$ & $\mathrm{df}$ \\
\hline \% Blastranformasi & 9.233 & 0.012 & .453 & 10 \\
Varian K3 dan P3 & & & .453 & 5.688 \\
\hline
\end{tabular}

Hasil analisis pada Tabel 3 dan 4 dapat diartikan bahwa tikus yang diasapi selama 7 dan 14 siklus estrus tidak mengalami gangguan imunitas seluler. Dari uji statistik persentase jumlah proporsi blastransformasi limfosit T kelompok K3 dan P3 (Tabel.5) berbeda bermakna $\mathrm{p}=0.01$. Hal ini menunjukkan bahwa tikus yang dipajan asap selama 21 siklus estrus mengalami gangguan imunitas seluler dibandingkan dengan tikus kelompok kontrol tanpa dipajan asap rokok. Pada penelitian ini asap rokok dan siklus estrus termasuk variabel independent, sedangkan variabel dependent yaitu blastransformasi limfosit $\mathrm{T}$, maka untuk menguji secara statistik pengaruh variabel independent dilakukan uji anova dua arah (Santoso S, 2001)
Tabel 6.

Uji Berganda menurut Least Significant Difference (LSD) Pada Kelompok Perlakuan P1 (7 siklus estrus), P2 (14 siklus estrus), dan P3 (21 siklus estrus)

\begin{tabular}{cccc|c|c|c}
\hline \multicolumn{2}{c}{$(\mathrm{A})$ ESTRUS } & (B)ESTRUS & $\begin{array}{c}\text { Mean Difference } \\
(\mathrm{A}-\mathrm{B})\end{array}$ & $\begin{array}{c}\text { Std. } \\
\text { Error }\end{array}$ & $\begin{array}{c}\text { Significan } \\
(p)\end{array}$ \\
\hline 7 & siklus & 14 & siklus & $-8.3650^{*}$ & 2.71717 & 0.004 \\
& & 21 & siklus & $-.8 .3158^{*}$ & 2.71717 & 0.005 \\
& & & & & & \\
14 & siklus & 7 & siklus & $8.3650^{*}$ & 2.71717 & 0.004 \\
& & 21 & siklus & .0492 & 2.71717 & 0.986 \\
& & & & & & \\
21 & siklus & 7 & siklus & $8.3158^{*}$ & 2.71717 & 0.005 \\
& & 14 & siklus & -.0492 & 2.71717 & 0.986 \\
\hline
\end{tabular}

Pada Tabel 6. terlihat bahwa tikus yang dipajan asap rokok antara 7 dengan 14 siklus estrus jumlah proporsi blastransformasi limfosit $\mathrm{T}$ sangat berbeda bermakna $(p=0.004)$. Jumlah proporsi blastransformasi limfosit $\mathrm{T}$ tikus yang dipajan dengan asap rokok selama 21 siklus estrus berbeda bermakna dibandingkan dengan pemajanan dengan asap rokok selama 7 siklus estrus $(\mathrm{p}=0.005)$.

\section{PEMBAHASAN}

Tujuan utama penelitian ini adalah menghitung secara kuantitatif proporsi blastransformasi limfosit T dari tikus betina setelah dipajan dengan asap rokok selama 7, 14, dan 21 siklus estrus. Hasil uji (T-test) tikus betina kelompok kontrol I (K1) dan perlakuan I (P1) 7 siklus estrus didapatkan jumlah proporsi blastransformasi limfosit $\mathrm{T}$ pada kedua kelompok tidak berbeda bermakna $\mathrm{p}=0.58$. Pada tikus betina kelompok kontrol II (KII) dan kelompok tikus yang dipajan dengan asap rokok II (PII), jumlah proporsi blastransformasi limfosit $\mathrm{T}$ pada kedua kelompok tidak berbeda bermakna $\mathrm{p}=0.85$. Pada tikus betina kelompok kontrol III (KIII) dan kelompok perlakuan (PIII) jumlah proporsi blastransformasi limfosit $\mathrm{T}$ kedua kelompok ini berbeda bermakna $\mathrm{p}=0.01$.

Hal ini dapat diartikan pada pemajanan 21 siklus sudah mempengaruhi imunitas seluler tikus perlakuan. Kemungkinan nikotin yang diterima oleh tikus yang terpajan 21 siklus sudah cukup konsentrasinya untuk mempengaruhi penurunan proliferasi limfosit $\mathrm{T}$. 
Dugaan ini berdasarkan penelitian Matsunaga (2001) yang mengkultur limfosit $\mathrm{T}$ dengan concanavalin $\mathrm{A}$ ditambah dengan nikotin konsentrasi tinggi, hasil kultur menunjukkan bahwa kultur dalam nikotin konsentrasi tinggi proliferasi limfosit T menurun. Penelitian yang dilakukan oleh Holt, 1977 pada tikus percobaan yang dipajan dengan asap rokok dalam waktu lama juga terjadi penurunan limfosit $\mathrm{T}$.

Proporsi blastransformasi limfosit $\mathrm{T}$ tikus betina yang dipajan dengan asap rokok pada kelompok PI, 7 siklus estrus dan kelompok PII, 14 siklus estrus menunjukkan sangat berbeda bermakna $\mathrm{p}=0.004$. Proporsi blastransformasi kelompok PI, 7 siklus dan kelompok PIII, 21 siklus estrus memperlihatkan sangat berbeda bermakna $\mathrm{p}=0.005$. Proporsi limfosit T tikus betina pada kelompok PII, 14 siklus estrus dan kelompok P III, 21 siklus estrus tidak menunjukkan penurunan yang bermakna $\mathrm{p}=0.986$.

Hasil blastransformasi PII bila dibandingkan dengan KII tidak memperlihatkan perbedaan yang berwarna, sedangkan hasil blastransformasi PIII bila dibandingkan dengan KIII menunjukkan perbedaan bermakna. Hasil ini menunjukkan kelompok PII tidak terganggu imunitas selulernya, sedangkan kelompok PIII sudah terganggu imunitas selulernya. Akan tetapi kalau dilihat blastransformasi PII dibandingkan PIII tidak berbeda bermakna. Ini mungkin disebabkan konsentrasi nikotin pada PII belum mencapai ambang batas untuk mempengaruhi imunitas seluler, sedang pada kelompok PIII sudah mencapai/ melampaui ambang batas terganggunya imunitas seluler. Hal ini juga dinyatakan oleh Kalra_2000, bahwa jumlah proliferasi limfosit $\mathrm{T}$ menurun pada tikus yang dipajan dengan asap rokok dalam waktu lama.

Hasil penelitian ini apabila diterapkan pada manusia kemungkinan tidak akan jauh berbeda. Oleh karena itu bagi perawat yang menjadi perokok pasif (terutama perempuan) kemungkinan daya tahan tubuhnya atau sistem imunnya akan menurun. Hal ini perlu diwaspadai dengan menciptakan lingkungan bebas asap rokok, baik di rumah maupun di rumah sakit.

\section{KESIMPULAN}

Zat yang terkandung dalam asap rokok dapat menurunkan blastransformasi limfosit T. Keadaan ini menandakan penurunan sistem imun selulernya. Untuk mengetahui penurunan sistem imun yang dapat membahayakan ketahanan tubuh manusia, perlu dilakukan penelitian lebih lanjut dengan pemajanan asap rokok yang lebih lama. Perlu juga dilakukan penelitian menggunakan rokok putih untuk mengetahui perbedaan gangguan kesehatan yang ditimbulkan $(\mathrm{HH})$.

\section{* Dana Penelitian dari Departemen Biologi FK-UI}

** Rosila Idris, Hadi Hartamto: Staf Akademik Departemen Biologi, Fakultas Kedokteran, Universitas Indonesia

\section{KEPUSTAKAAN}

Coligan JE, Bierer BE, Margulies DH, Shevach EM, Strober W. (2005). Culture For Mitogen-induced Proliferation of peripheral Blood Mononuclear Cells. Dalam: Text-book Short Protocols in Immunology. Published by John Wiley \& Sons, Inc.

Gunawan, S. (1981). Rancangan Percobaan. Penataran statistik terapan. Jurusan Matematik FIPIA-UI, Jakarta. Tidak dipublikasikan

Holt, PG., Keast, D. (1977). Environmental Induced Changes in Immunological Function: Acute and Chronic Effects of Inhalation of Tobacco Smoke and Other Atmospheric Contaminats in Man and Experimental Animals. Bacteriological Reviews; Vol 41. (1), 2005-216.

IARC (International Agency for Research on cancer). Monographs on the Evaluation of of Carcinogenic Risk of Chemicals to Humans. Tobacco Smoke and Involuntary Smoking. IARC, Lyon, France 2004; Vol 83. 
Kalra R, Singh SP, Savage SM, Finch GLand Mohan L. Effects of Cigarette Smoke on Immune Response: Chronic Exposure to Cigarette Smoke Impairs Antigen-Mediated Signaling in T Cells and Depletes IP3-Sensitive $\mathrm{Ca}^{+}$Stores. Society for Experimental Biology and Medicine 2000; Vol.293, Issue 1, 166-171.

Matsunaga K, Klein TW, Friedman H, and Yamamoto,Y. Involment of Nicotinic Acetylcholine Receptors in Sppression of Antimicrobial Activity and Cytokine Responses of Alveolar Macrophages to Legionella pneumophila Infection by Nicotine. J. Immunol. 2001; 167(11): 6518-6524.
Matangkasombut $\mathrm{P}$ and Tharavanich S. Lymphocyte transformation agents. Second Regional Workshop in Immunology, Bangkok, 21 August - 1 September 1972.

Santoso S. Mengolah data Statistik Secara Profesional. SPSS Versi 10. Penerbit PT Elek Media Komputindo Kelompok Gramedia-Jakarta, 2001.

Sheung PNg, Steinets BG, Lasano SG, and Zelikoff. Hormonal Changes Accompanying Cigarette Smoke-Induced Preterm Births in a Mouse Model. Experimental Biology and Medicine, 2006; 231(8): 1403-1409.

Yusuf, A dan Saad, A. (1991). Merokok pasif. Makalah Bagian PulmunologiFKUI/ Unit Paru RS Persahabatan Jakarta. Tidak dipublikasikan 